\title{
Representation in Westminster in the 1990s: The Ghost of Edmund Burke
}

\section{DAVID JUDGE}

\begin{abstract}
Why are 'trustee' notions of representation still invoked in the UK House of Commons in the 1990s? In answering this question this article analyses the premises of Burkean theory and the arguments that these premises are of little relevance in the late twentieth century. Despite these dismissals of trusteeship, Burkean ideas are still articulated in the Commons some 200 years after they were first voiced. The idea of trusteeship can prove extremely useful to justify the actions of representatives when those actions conflict with constituency 'opinion', party policy or the wishes of interest groups. Examples of the occasions when Burkean notions have been invoked in the 1990s are provided.
\end{abstract}

\section{BURKE: THE PARADOX ${ }^{1}$}

Writing in this journal Philip Cowley pointed to the continuing paradox of how Members of Parliament deal with 'conscience issues' in the Commons: '[It is] curious that on such important issues the British democratic system goes haywire: on almost all other issues, no matter how small, we have a system of party democracy. Yet on issues that actually matter to people we revert to a system of 659 independent MPs, all allowed to vote with their consciences. ${ }^{2}$ This paradox becomes even more pronounced in the empirical finding that, when MPs are freed from the constraints of the party whip on 'conscience' issues, party still remains the most powerful variable explaining the votes of individual MPs. ${ }^{3}$ In fact, Cowley found that party cohesion was greater in the 1992-97 parliament on some of these supposedly 'non-party' matters than on votes with a three-line whip. Implicit within Cowley's analysis is a criticism of the continuing practice of allowing free votes on issues of conscience when party considerations still appear to influence the outcome in the Commons. As he concludes, 'most of the beliefs about conscience issues in the House of Commons are false ... 
and [hence] the current practice of treating conscience issues as a breed apart deserves questioning'. ${ }^{4}$

Throughout, Cowley's analysis is haunted, implicitly at least, by the ghost of Edmund Burke and other 'trustee' theories of representation. The fundamental question raised by Cowley's analysis is: why are 'trustee' notions of representation still invoked in the 1990s? However, this question extends beyond the immediate concern of 'conscience issues' to encompass a discussion of the very nature of representative democracy in Britain as we head towards the twenty-first century.

\section{EDMUND BURKE AND TRUSTEE THEORY 5}

Although the essence of trustee theory is remarkably simple representatives should use their independent judgement in reaching decisions and should not be bound, therefore, by instructions from their electors - the premises upon which this simple conclusion is reached are in fact remarkably complex. Burke's position, and that of Whigs more generally, revolved around three assumptions: first, representation was to be of particular geographical constituencies by particular Members of Parliament; second, the purpose of representation was to constitute a deliberative body; and, third, parliament was to play a leading role in the process of decision making. In essence this was a defence of the constitutional settlement of 1689, and of the 'balanced constitution' of crown-in-parliament, with parliament in the ascendant and charged with 'deliberating and pronouncing on the public interest and the common good'. ${ }^{6}$ In occupying this leading role in state policy making, Whigs contended that parliament 'should not only give expression to the various opinions, interests, and grievances within society, it should also try to reconcile them in policies which would serve the best interests of the nation'. ${ }^{7}$ Yet here was the central conundrum of Whig thought, for if representation was territorially based and interest-centred, how could it simultaneously secure the promotion of a wider national interest through consensual state policies? If a representative was locally elected to pursue specific territorially linked economic interests, how could he (in an era before the female franchise) be expected to articulate and advance the national interest? The answer provided by Burke was simple and to the point: there was no problem here. To understand his answer, we need to analyse Burke's conception of representation serially; to start with the relationship between individual constituency and individual representative, and then to examine the collective relationship of elected representatives within parliament. 


\section{Constituency-Representative Relationship}

Burke's conceptualisation of the proper relationship between constituency and representative appears, initially, to be paradoxical. On the one side, the representative is expected to pursue the interest of his constituency; yet, on the other, once in the confines of Westminster the representative 'is not a member of Bristol [a constituency], but he is a member of parliament [the nation $]^{\prime} .^{8}$ If this is the case then the duty of the representative is to the nation as a whole, and as such he 'stands in no special relation to his constituency' . ${ }^{9}$ Yet, for Burke, there is no paradox because the interest of the constituency is, ultimately, congruent with that of the nation as a whole.

Individual constituencies were broadly defined in terms of a pre-eminent economic interest and their prosperity was correlated closely with the promotion of that interest. In effect, this was simply a reflection of traditional notions of representation, where members of the Commons were returned by small, economically powerful local electorates. In this context it made sense to associate specific constituencies with specific interests whether mining, agriculture, trading, shipping, or some other commercial interest. Two corollaries stemmed from this conception of constituency interest. First, as this interest was objective it was apparent to constituent and representative alike. In other words, the representative did not have to be told what the interest was, nor did he need to receive instructions as to how best to advance that interest. As Pitkin makes clear, constituency interest was thus seen to be 'unattached' - 'an objective reality ... apart from any individuals it might affect'. ${ }^{10}$ The second corollary was closely linked to the first in that Burke rarely saw 'interest' linked to specific individuals. Indeed, he was fundamentally opposed to the representation of 'individuals' and their interests, opinions and wishes. Individual opinion, especially when aggregated into 'public opinion', was invariably misguided. In which case he maintained that only when the opinions of 'the multitude are the standard of rectitude, shall I think myself obliged to make those opinions the master of my conscience'. ${ }^{11}$ In the absence of such rectitude, however, Burke was willing to inform his own constituents that his duty was to maintain 'your interest even against your opinions'. ${ }^{12}$

At the end of the eighteenth century this was a defensible position for a Whig to adopt as it simultaneously protected the existing narrow geographical franchise (which effectively excluded rapidly developing urban areas from parliamentary representation) as well as challenging radical and liberal ideas that 'individuals' should be the basis of representation. Despite the significant growth and shifts in population to urban areas the representation of counties and boroughs had remained largely unchanged. In response, the movement for parliamentary reform 
began to organise in the 1770 s and to demand 'equal representation of the whole body of the people', ${ }^{13}$ annual parliaments and the redistribution of parliamentary seats. Yet, for Burke, the fact that many of the new industrial cities had no representatives in parliament was not a matter of concern: they were represented 'virtually'. In this view, as long as there were representatives from other constituencies with similar commercial, agricultural or manufacturing interests, the interests of all other localities with these same interests could find representation in parliament - even though those localities were not directly represented therein. Hence, although there was not 'actual' representation there was 'virtual' representation. The latter occurred where 'there is a communion of interests, and a sympathy in feelings and desires between those who act in the name of any description of people, and the people in whose name they act, though the trustees are not actually chosen by them'. ${ }^{14}$ 'Such a representation I think to be, in many cases, even better than the actual. ... [C]ommon interest and common sentiment are rarely mistaken'. ${ }^{15}$ At its simplest, therefore, the representative for Bristol, in looking after the interest of Bristol, would also be looking after the same economic interest wherever it is located. The logic is that 'Birmingham is virtually represented in ... parliament because both it and Bristol are of the trading interest. Bristol sees to it that a representative of the trading interest is sent to Parliament, and Birmingham thus has its spokesman'. ${ }^{16}$ However, for this logic to prevail two other conditions were required: first, that a representative would listen to his own constituents and be electorally responsible to them; and, second, that his actions in parliament should not be bound or mandated by them.

The first condition is necessary to ensure that representatives continue to promote their own constituency interests. Elections are the medium by which representatives are kept in tune with constituency interest. But elections are a reactive and not a proactive mechanism. Their purpose is not to express policy preferences but to assess the efficacy of representation and to decide how far a constituency's economic interest has been protected. In theory, 'every general election is to the representative a day of judgement, in which he appears before his constituents to account for the use of the talent with which they intrusted him, and for the improvement he has made of it for the public advantage'. ${ }^{17}$ Again, if interest is objective, and if both representative and electorate alike know what it is, then there will be no fundamental disagreement between them. In Burke's words: 'Certainly, Gentlemen, it ought to be the happiness and glory of a representative to live in the strictest union, the closest correspondence, and the most unreserved communication with his constituents.... It is his duty to sacrifice his repose, his pleasure, his satisfactions, to theirs - and above all, ever, and in all cases, to prefer their interest to his own'. ${ }^{18}$ Elections are essential, however, in 
those cases where representatives start to prefer - whether through corruption or incompetence - their own interest to that of their constituents. If there is long-term disagreement between constituents and representative then there must be something wrong. Ultimately, this is a negative assertion on Burke's part of the value of elections, as it holds that 'a lasting discrepancy between the member and the people is / «consistent with true representation'. ${ }^{19}$

The second condition is that a representative should neither be bound by instructions from his constituents, nor act as their delegate in parliament. In part, this was because Burke believed public opinion to be invariably illinformed and unstable. In which case, he saw it as his duty as a representative 'to give them information, and not receive it from them ... I should be ashamed to show my face before them, if I changed my ground as they cried up or cried down men or things or opinions - if I wavered and shifted about with every change'. ${ }^{20}$ In part also, it was because Burke believed in the superior capacities of a natural aristocracy who 'acted as the paternal guardians of the countless communities which together made up the kingdom. These men should not slavishly follow the transient whims of popular prejudice'. ${ }^{21}$ Government should thus remain in the hands of this aristocracy rather than be placed in the hands of the people. An enlightened elite was to exercise power on behalf, not at the behest, of the people. This did not mean that the elite was unresponsive to the electorate. Far from it, because 'the people are the masters'. ${ }^{22}$ 'But', and it is a significant 'but', '[t]hey have only to express their wants at large and in gross. We [MPs] are the expert artists; we are the skilful workmen, to shape their desires into perfect form, and to fit the utensil to the use' ${ }^{23}$

\section{Collective Relationship of Elected Representatives within Parliament}

It is at this point that our attention comes to be redirected away from the individual relationship between representative and constituency towards the collective relationship of elected representatives within parliament. But Burke's view of the collective role of parliament is predicated upon his view of society as being organic and differentiated with a paternal, aristocratic elite acting as the guardians of communities of the realm. In this sense Burke was the defender of 'aristocratic trusteeship'. ${ }^{24}$ Whilst representation ensured that political power was to be exercised ultimately in the interest of the represented, the represented themselves were, for the reasons outlined above, to have little direct influence upon public policy. It is as well at this stage to underline, therefore, that Burke's ideas had little in common with modern notions of responsible government. Overall, Burke was dismissive of the view that individuals should count equally in politics and especially contemptuous of notions of popular representation. For him democracy was 
tyranny: 'The tyranny of the multitude is but a multiplied tyranny. ${ }^{25}$

The purpose of representation instead is to allow the 'true natural aristocracy' to discover and enact the national interest. An interest, moreover, which holds paramount the defence of property against the great masses. Thus the role of representatives collectively is to identify the national interest. State policy should thus reflect the interest of the whole, and, for this reason, representatives in parliament should not be mandated or bound by instructions from their constituents. Only through deliberation and the consideration of the broad range of constituency interests in the House of Commons could consensus be reached upon the national interest. The promotion of 'narrow' and 'sectional' interests by constituency delegates would not only frustrate this objective but in fact would be 'utterly unknown to the laws of this land' and would arise from a fundamental misconception 'of the whole order and tenor of our constitution'. ${ }^{26}$ It is in this context that Burke's famous Address to the Electors of Bristol should be read:

Parliament is not a congress of ambassadors from different and hostile interests, which interests each must maintain, as an agent and advocate, against other agents and advocates; but Parliament is a deliberative assembly of one nation, with one interest, that of the whole - where not local prejudices ought to guide, but the general good, resulting from the general reason of the whole. You chose a member, indeed; but when you have chosen him he is not a member of Bristol, but he is a member of Parliament. ${ }^{27}$

All the different communities founded upon various forms of property thus have an ultimate interest in the well-being of the whole. The 'national interest' is conceived merely as the aggregation of the objective economic interests represented in localities.

Only parliament can discover the national interest through the articulation of constituency interests in discussion. Armed with this information, each and every representative will be able to assess the merits of each argument, and in the course of a complex process of deliberation will be able to discover the national interest. Hence, the result of parliamentary discussion is the rational formulation of the interest of the whole and consensus. But this agreement will only emerge if MPs are not bound by the opinions of their constituents. Precisely because constituents were not present at the discussions in parliament they could not know what the national interest is at any given time, and precisely because they do not have this knowledge they should give their representatives the freedom to act as they see fit to determine and promote the national interest. In which case, 'if the local constituent should have an interest or should form an hasty 
opinion evidently opposite to the real good of the rest of the community, the member for that place ought to be as far as any other from any endeavour to give it effect'. ${ }^{28}$

Burke's view on representation is thus complex and interweaves various ideas about the British constitution, and the political balance pivoted around the constitutional settlement of 1689; about the nature of property, and the objective nature of economic interest; about society and its organic nature; and about the virtues of aristocratic leadership. It is within this context that his views about trusteeship have to be analysed. His was not a universal claim to 'independence' on the part of representatives. In fact, it was a specific claim made in a specific historical period to address specific problems occasioned by the rise of political parties and the demands for parliamentary reform. The irony, therefore, is that Burke's argument, which received little prominence at the time, ${ }^{29}$ became central to the formulation of the issue of democratic representation in later centuries despite its antidemocratic premises.

\section{TRUSTEE THEORY AND MODERN NOTIONS OF REPRESENTATION}

There are, of course, many commentators and politicians in the 1990s who point to the pre-democratic origins of trustee theory and argue that notions of 'trusteeship' are of little relevance to the political circumstances of modern Britain. They claim that the development of an educated citizenry, a mass electorate, political parties and party government have all served to undermine Burkean notions of representation. This case is presented most starkly in Bealey's judgement that: 'Burke is largely irrelevant, for he lived in the era of limited suffrage before there were mass parties. ${ }^{130}$ Other academics are content simply to stress that 'the heyday of this strongly elitist view was in the nineteenth century before the rise of organised parties'. ${ }^{31}$ Likewise, MPs, particularly Labour MPs, have argued that: 'It is time Burke was put in his place - Burke was no democrat and since he spoke a new world has been born. We do not live in Burke's world anymore. ${ }^{132}$ Conservative MPs have also been willing to acknowledge the anachronistic character of Burke's argument. Speaking in the debate on the Criminal Justice Bill in April 1987, Michael McNair-Wilson, Conservative MP for Newbury, stated:

I suggest that the comments of an 18th century politician [Burke] are not really relevant at the end of the 20th century. He spoke when Parliament was of a different stamp, when the populace was largely illiterate and uneducated and did not possess television, radio or masscirculation newspapers. It could scarcely claim to be informed. That 
society cannot be compared with our own. We now have a highly educated populace that is well informed and articulate. In these times those outside the chamber are as well equipped as we are to make a decision on their individual safety and the safety of their community. ${ }^{33}$

Indeed, there are now those who maintain that Burkean principles of trusteeship are a threat to the democratic process itself. This fear was articulated by Geoff Mulgan, director of the independent think-tank Demos:

Edmund Burke's famous argument [was] that electorates should trust MPs to vote with their judgement, not as delegates. The principle was crucial to the rise of parliaments in the late 18th and 19th century when most "informed opinion" viewed democracy as a road to irrational mob rule and tyranny. Yet as the decades passed, and popular pressure forced extensions of the franchise, it turned out that ordinary people were, after all, wiser than their rulers had feared, and generally happy to leave the great decisions to their betters in Parliament.

But as politicians' public esteem has collapsed ... the Burkean principle has come unstuck. Trust has been eroded and many have come to see politicians as barriers against, rather than tribunes for public opinion. ${ }^{34}$

Yet, despite these dismissals of trusteeship, Burkean ideas are still articulated over 200 years after they were first voiced. Indeed, the Edmund Burke Society sent every member of the new House of Commons of May 1997 a copy of Burke's speech to the electors of Bristol, and at least one MP found that: 'it made terrifying reading in terms of the illumination that it offered to the Government's programme and our general situation because it was so deeply contemporary'. ${ }^{35}$ Admittedly, however, the occasions upon which Burkean notions are advanced are now limited and tend to justify specific instances where representatives deem that they have a right to use their individual judgement. In other words, no British MP in the 1990s would claim to act exclusively as a trustee, beholden only to his or her own conception of the national interest. Instead, the reality of modern parliamentary politics is that MPs are primarily representatives of their party, increasingly attentive to their constituencies, as well as being receptive to the claims of organised interests within society. ${ }^{36}$ In this sense diverse conceptions of representation - party, collectivist and interest representation - co-exist and contend with longer established Whig and liberal notions. The practice of representation is thus far from uni-dimensional. ${ }^{37}$

The real significance of Burkean ideas about representation is that they preceded the dominant conceptions of party and collectivist notions, and 
indeed provided the frame within which later ideas had to be accommodated. Yet these later conceptions did not entirely supersede or totally replace notions of trusteeship; instead, new ideas were grafted onto existing theories to produce a mixture in which no single theory became hegemonic. This analytical point is well expressed by Birch when he notes that: 'As circumstances changed, so fresh theories were formulated to meet them, but it cannot be said that the fresh theories have generally replaced the older ones ... the more usual development has been for the fresh theory to take its place alongside the older ones as an additional strand in the British political tradition. ${ }^{38}$ In this respect, 'old theories' still retain a legitimate place in the debate about representation. In fact, it is the legitimation afforded by such theories to MPs' actions that sustains the intensity of this debate.

The simple, but extremely important, point is that modern representatives in Britain may draw upon a range of ideas, each legitimate in their own terms, to defend or justify their actions. One example of this was provided in Nigel Forman's evidence to the Nolan Committee. ${ }^{39}$ In sketching the 'duties and opportunities' of MPs he provided six analytical categories of activities: four related in one sense or another to the representation of 'interests', a fifth was 'loyalty to their parties in Parliament and in the constituency'; but, 'first of all, MPs have a duty to their constituents and on certain issues to their consciences as well. One thinks, for example, of the classic issue of capital punishment... and I would say that all MPs, without exception, recognise that duty and perform it to the very best of their ability'.

The fact that different conceptual bases of representation co-exist enables MPs at different times to call upon different, seemingly contradictory, conceptions of representation. Burkean notions tend to be reserved for occasions when MPs find themselves in conflict with the premises of other theories - whether of individualistic, party or 'interest' representation. The idea of trusteeship can prove extremely useful to justify the actions of representatives when those actions conflict with constituency 'opinion', party policy or the wishes of interest groups. On some issues especially 'conscience' issues - MPs may find themselves in conflict with all three simultaneously.

\section{Conscience Issues}

As Cowley notes, there are a number of issues which have been treated as matters of 'conscience' in modern parliamentary politics. All recent votes in the House of Commons on, for example, abortion, capital punishment, hunting, seatbelts and the treatment of war criminals have not been the subject of the party whip. Similarly, some, but not all, votes on the issues of 
homosexuality and family law reform have been unwhipped. The outcomes of these votes have been of some significance in the daily lives of many people in Britain in the 1990s. The most powerful variable in explaining the way that individual MPs vote on these issues is 'party'. Cowley and Stuart ${ }^{40}$ found, for instance, that on 12 free votes on 'issues of conscience' between 1979 and 1996, on most occasions the majority of each of the major parties voted in opposite lobbies. On only four issues - voluntary euthanasia, war crimes, lowering the age of consent for male homosexual acts and legalisation of embryo research - was a majority of Labour and Conservative MPs to be found in the same lobby. In this respect 'conscience' issues are not 'non-party' issues. In fact, party cohesion was greater in the 1992-97 parliament on some of these supposedly 'non-party' matters than on votes with a three-line whip. ${ }^{41}$

On the basis of these findings Cowley is led to question the continuing practice of allowing free votes on issues of conscience when party considerations still appear to influence the outcome in the Commons. Yet his own findings reveal that there were internal splits, with significant minority opinion, within the Conservative Parliamentary Party on five issues and within the Parliamentary Labour Party on three other issues. These internal divisions reflected wider divisions within the parties beyond Westminster and within the electorate at large. Given the uncertainties of mobilising support, it is not too surprising to find, therefore, that party managers remain willing, on pragmatic grounds, to allow for the invocation of Burkean notions of independent judgement. More particularly party managers are aware of the advantages in justifying, in terms of established representative theory and practice, what can only be called non-democratic decisions (where a majority of the electorate are in favour of a particular policy but the majority of party MPs are opposed, with capital punishment providing the most clear-cut example). Hence, Burkean notions of independence retain a pragmatic utility in the legitimation of decisions in the 1990 s as well as a principled rationale for the taking of electorally unpopular decisions.

The issue of capital punishment has provided a particularly visible 'fault-line' which has highlighted the continuing relevance of Burkean notions of representation for MPs. This divide was evident in the debate in February 1994 on a proposed amendment to the Criminal Justice and Public Order Bill which would have reintroduced capital punishment for the murder of a police officer. On that occasion, Tony Blair, then Labour frontbench spokesman on Home Affairs, strongly defended a trustee position: 
I understand why a majority of my constituents, and perhaps a majority of people in the country, will answer yes to the question, 'Do you favour the death penalty?' They are angry and outraged at the murders and killings in our society. However, I would like ... to reflect upon the fact that, in every debate on the subject that I have witnessed, the value of the debate has become obvious as it has proceeded and as we have moved from general and instantaneous reaction to the particular and the considered. Suddenly answers that appeared obvious become more complex and conclusions that seemed certain are open to doubt. Such a large majority of Members did not vote against the restoration of the death penalty on each occasion because they were unaware of their constituents' views but because, on reflection and after considered debate, they could not support those views....

I certainly do not believe that my understanding is superior to that of my constituents, but ... we are representatives, not delegates, and we must act according to our conscience. ${ }^{42}$

What is of significance in Blair's statement is the emphasis placed upon deliberation and the process of rational discourse in parliament. Here is a direct echo of the emphasis placed upon deliberation in the theories of Burke and J.S. Mill. An even more direct echo of Burke, indeed almost a paraphrasing of his 1774 Speech to the Electors of Bristol, is to be found in Betty Boothroyd's contribution to the debate on the Criminal Justice Bill in April 1987:

My final argument ... is about the democratic process, because it brings into conflict individual conscience and what I regard as majority opinion. ... Since first being elected to the House, I have consistently demonstrated my opposition to judicial killing, although in all honesty I cannot say that all my constituents are aware of my views. But I take the view - I believe that my constituents share it with me - that I am not a mandated delegate, and this is not a delegated assembly. I owe respect to the people whom I represent for their point of view. I also owe them my judgement in seeking what is right and best for the country in its entirety.

It would not be wrong in itself, but wrong in the interests of the nation, to reinstate capital punishment on the basis of public opinion. That opinion I must face and convince. If I fail, my views and I can be rejected. It would be intolerable if I were to allow public perception rather than convincing argument to blow me away from the opinions that I hold. ${ }^{43}$ 
For other representatives, however, the 'democratic process' requires that MPs should 'not run too far ahead of public opinion in any matter'. ${ }^{44}$ For supporters of capital punishment the particular danger is that 'Members of Parliament risk distancing themselves from the views of people outside. We are becoming less representative on this matter'. ${ }^{45}$ In which case, therefore, 'The House and we as Members should reflect public opinion ... It has never been clear to me why the House continues to ignore such public opinion'. ${ }^{46}$ But even in these latter statements the warrant of public opinion is specific and not universal. Thus, Rhodes Boyson offered the qualification that 'I do not say that we should do everything that they [the people] want, but we should listen to them'. ${ }^{47}$ Similarly, Elizabeth Peacock maintained: 'I do not believe that Members of Parliament are delegates because we are not... the measure is a matter of conscience. ${ }^{148}$

The linkage between electors and elected is thus contingent rather than absolute. Burkean trusteeship confers upon the representative the discretion to choose when to heed the opinions of their constituents and when not. MPs do not dispute that they should be responsive to their party supporters and leaders and to their wider electorates; but the exact degree of responsiveness is balanced by a fine calculation of competing imperatives party, constituency, group interest, personal morality or conviction. The very contingency of decision leads to inconsistency in the claim made on behalf of 'independence' - even by the same MP. This inconsistency was encapsulated in the exchange between Jack Straw (Secretary of State for the Home Department) and Andrew Robathan (Conservative MP for Blaby) during the second reading of the Firearms (Amendment) Bill in June 1997. This bill sought to effect the Labour party's manifesto commitment for a complete ban on all handguns:

Mr Jack Straw: I strongly commend the Bill's proposals to the House, but I want to make it crystal clear that - as in opposition - it will be a matter for my hon. Friends' individual consciences to decide whether to support or oppose the measure tonight. But none of us should doubt the overwhelming public support for the proposed ban. For only one indication of the extent of public support for a complete handgun ban, I draw the attention of the House to the results of an opinion poll in The Daily Telegraph last Friday, which showed that 83 per cent of those polled approved of the Government's proposed ban on all handguns.

Mr Andrew Robathan (Blaby): The opinion poll may or may not be correct, but on that logic, the Home Secretary would be introducing a Bill to reinstate capital punishment. Every time there is a poll on that 
subject, 75 per cent, of people are in favour. That is not a good argument for the Bill.

Mr Straw: I do not accept the premise of the hon. Gentleman's argument. Of course, it is in the end a matter for the individual consciences of hon. Members, but in making our decisions, we must take account of the strength of public feeling. I do not think that anything like 83 per cent, of people are in favour of capital punishment, but I am well aware that I may not have had my constituents' support when I have marched into the Lobby against it. That is a fact that I have to take into account, but it does not stop me. ${ }^{49}$

The extent to which notions of 'independence' and 'conscience' had become embedded in the discussion of the issue of capital punishment in the House of Commons in the 1990 s is revealed in the debate surrounding the Human Rights Bill of 1997/98. The bill gives effect in UK domestic law to the rights contained in the European Convention on Human Rights (ECHR). Protocol 6 of the ECHR requires the complete abolition of the death penalty other than in time of war or imminent threat of war. In introducing the Human Rights Bill the UK government sought a reservation on enacting Protocol 6. It did so on the grounds that although

there might appear to be little difficulty in our ratifying Protocol 6. This would, however, make it impossible for a United Kingdom Parliament to re-introduce the death penalty for murder, short of denouncing the European Convention. The view taken so far is that the issue is not one of basic constitutional principle but is a matter of judgement and conscience to be decided by Members of Parliament as they see fit. For these reasons, we do not propose to ratify Protocol 6 at present. ${ }^{50}$

At the Common's committee stage of the bill, Kevin McNamara introduced Amendment 111, which sought (successfully) to overturn this reservation, and to insert the sixth protocol into the bill. Opponents of the amendment expressed some difficulty in following the logic behind Mr McNamara's argument:

At the outset he [Mr McNamara] said, properly, that the issue of capital punishment is one for conscience and a free vote, and at any time it chooses the House can debate that issue as it relates to individual instances - whether it be treason or piracy or whether the death penalty should apply in wartime - but would not the effect of what he proposes be to fetter the ability of Parliament to express its conscience? If we accept the protocol as the hon. Gentleman seeks to 
admit it, it would no longer be open to Parliament to debate that issue without, effectively, throwing out the whole European convention, lock, stock and barrel, or at least changing it. Acceptance of the protocol would introduce an extra hurdle, which fetters Parliament's ability to express its conscience on a matter which, I am sure that he will agree, is of widespread public importance, and often discussed. ${ }^{51}$

The same view was expressed by James Clappison (MP for Hertsmere):

It is right and appropriate that these matters should be decided, now and in the future, by the individual judgments and conscience of Members of the House on a free vote. The Minister was not giving away inside information that would bankrupt anyone in the bookmaking profession when he said that it was unlikely in the present Parliament that there would be a majority in favour of the return of the death penalty. That is true, given the present composition of the House. ${ }^{52}$

While supporters of Amendment 111 were willing to accept that the issue of capital punishment 'has to be determined by Members of Parliament after rigorous examination of their consciences', ${ }^{53}$ they maintained, nonetheless, that the decision on Protocol 6 was equally a matter of individual conscience. In reply, Mike O'Brien, Parliamentary Under-Secretary at the Home Office, voiced the concern that:

My personal view and that of the Home Secretary is that Parliament should be free to decide on death penalty matters on a free vote and that protocol 6 would make a free vote difficult. Ratification of the protocol, from which no derogation or reservation is permitted, would interfere with the ability of a United Kingdom Parliament to consider the issue in future, short of effectively denouncing the convention. ${ }^{54}$

Mr O'Brien made it clear, however, that his was indeed a personal view, and that 'as far as the Government are concerned, this is a free vote ... This [the vote on Amendment 111 ] is a matter of conscience for hon. Members', ${ }^{55}$ In the vote 294 members used their 'consciences' to support the amendment, while 136 followed Mr O'Brien into the 'no' lobby. Once again, the ghost of Burke stalked the lobbies of Westminster.

\section{TRUSTEE v. PARTY DELEGATE}

Despite affirmations that MPs are not delegates, there is one specific sense in which they consistently act as delegates and that is in relation to their party. Although the theory of 'party representation' - and its corollaries of 
the electoral mandate and party cohesion within parliament - is essentially the preserve of the Labour Party, the practice of collectivist representation extends to all parliamentary parties. The impact of party, even on nominally 'non-party' issues of conscience, was noted above; but the strength of party in influencing MPs' actions in parliament is indicated more powerfully in the findings of a survey, conducted by the Study of Parliament Group, ${ }^{56}$ of newly elected MPs in 1992. Of 79 respondents (61.4 per cent of all 127 new members) well over four-fifths maintained that their voting decisions and parliamentary actions would 'usually', or 'nearly always', be 'strongly influenced' by their party leadership. Ninety-six per cent of Labour respondents believed this to be the case, as indeed did 84 per cent of new Conservative respondents.

What is equally notable, however, is that 71 per cent of Labour respondents and 85 per cent of Conservatives in the 1992 sample also said that their 'personal opinions' would be expected to influence their parliamentary actions and voting decisions. In 1997, 85 of 114 newly elected MPs (75 per cent) who responded to the Study of Parliament Group's survey still subscribed to the view that MPs should exercise their independence. In other words, party theory coexists with trustee theories in the minds of newly elected MPs. There is, therefore, a potential for these divergent notions to come into conflict. When they do, either theory may be invoked to legitimate, or challenge, the actions of MPs. A clear illustration of this clash was provided in the battle over intra-party democracy within the Labour Party in the early 1980s. Supporters of the party theory of representation chose to criticise the Parliamentary Labour Party because:

Most Labour MPs appear to have the same conception of their role as do Tory and Liberal MPs. They see themselves as representatives very much as defined by Burke: they claim the right to exercise their individual judgement, and on that basis to treat the Party's Election Manifesto and Programme as little more than advisory. ${ }^{57}$

What was needed, from this perspective, was to make MPs and the parliamentary leader more accountable to the wider labour movement. Not surprisingly, the reforms effected in 1980 and 1981 - the introduction of the mandatory reselection of Labour MPs, and the establishment of an electoral college for the selection of the party leader - sought to ensure just that. One consequence of adopting these constitutional changes was that the inherent tension between conceptions of parliamentary representation within the party was heightened, with three of the most vociferous opponents of the internal reforms - David Owen, Shirley Williams and William Rodgers voicing their objections to the proposed changes in Burkean terms: 
For decades debates on policy and organisation have gone on within our party, and we have managed to find some way of working together. But this time the far left wants no compromise. It is seeking not only to dominate the party, but to destroy representative democracy itself. MPs are chosen by their constituents to exercise their conscience and judgement. MPs ... who are nothing but mandated party delegates cannot be representatives of their constituencies in the true sense. They cease to be accountable to the people who elected them and become instead the rubber stamps for a party caucus, one that does not even include the majority of party members. ${ }^{58}$

So great was the fear that Labour MPs would be expected to act as delegates of their constituency party activists that 28 Labour MPs chose at the time to leave the party to join the Social Democratic Party. Even those MPs who were willing to remain within the Labour Party expressed their concern at the possibility of being subject to the diktat of constituency activists 'instructing elected representatives how to behave, regardless of their electors' views'. ${ }^{59}$

However, invocation of Burke is not exclusively the preserve of embattled Labour MPs, as Conservative and Liberal Democratic MPs are just as likely to call upon trustee conceptions of representation when in conflict with their constituency parties, or in disagreement with party policy. Thus, for example, David Alton MP announced, in September 1992, that he would not stand as a Liberal Democrat parliamentary candidate at the next election in protest at the decision taken at the party's conference to make abortion a policy issue rather than a matter to be decided by individual conscience. ${ }^{60}$ More dramatically, in the Conservative Party in the aftermath of Mrs Thatcher's resignation as party leader in 1990, eight constituency associations organised meetings to consider the deselection of their MPs most notably Julian Critchley, Michael Mates and Ivor Stanbrook - who had actively sought Mrs Thatcher's replacement as party leader. On this occasion, the leader-writer of The Independent counselled Conservative activists to remember that:

Members of Parliament are not delegates who can have their mandate withdrawn at the whim of local party activists. The Conservative Central Office guidance manual for intending parliamentary candidates specifically states that Tory MPs once elected, should be free to exercise their own judgement within the very wide ambit of Conservative principles. ${ }^{61}$ 
George Gardiner, Conservative MP for Reigate, felt the need to remind his local party of this freedom in his battle against de-selection before the general election of 1997. His constituency association sought his deselection on the grounds of repeated 'disloyalty to the Prime Minister and the Cabinet'. Gardiner's response was to invoke Burke: 'An MP is not a sheep. He must follow his own convictions', ${ }^{62}$ and, more explicitly: 'Reigate Conservatives will have to decide whether a Member of Parliament is sent to Westminster purely as lobby fodder, or whether he should exercise his own judgement on matters of supreme national importance. ${ }^{163}$

\section{Conservative MPs and Europe}

Throughout the 1990s most Conservative MPs identified the issue of European integration to be of 'supreme national importance'. ${ }^{64}$ In these circumstances, the certainties of intra-party support and cohesion gave way to a contingent relationship between vertical groupings of opinion within the governing party. Not surprisingly, Burke was cited in defence of the necessary 'independence' asserted by one faction in face of the other. The malleability of 'trusteeship' and its contemporary relevance can be gauged from its deployment by those both in support of, and in opposition to, the Conservative leadership's European stance at any given moment. The respective claims revolved around who could best decipher the 'best interests of the electorate'. Both sides agreed, however, that it was not the electorate itself. Thus, those opposed to allowing the electorate to vote in a referendum on the question of a European single currency maintained that Burke was on their side:

All of us who have been in the House for a long time have taken difficult decisions on many issues. Those include moral issues, such as capital punishment and changes in the abortion laws, and constitutional issues such as the treaty of Maastricht, the Single European Act 1986 and, before I came here, the treaty of Rome. I agree strongly with Burke, who when speaking to the electorate of Bristol said: "Your representative owes you not his industry only, but his judgment. And he betrays, instead of serving you, if he sacrifices it to your opinion". That is not a popular view ... If the House is to retain respect, we must have the courage at times to follow our own judgment and, having listened carefully, not to be swayed from that. ${ }^{65}$

In the same debate, Sir Terrence Higgins upheld the view that MPs 'come to the House as representatives, not delegates':

We are not here to function as a surrogate calculating machine, to vote the way that our constituents would if they could all press a button. 
We have a much greater responsibility to consult our constituents and listen to their arguments, but it is the strength of the argument and not the number of people who make it that is important. Then, we must weigh up the arguments and vote as our constituents would if they had the advantage that we do of listening to debates and analysing the issues. ${ }^{66}$

If Burke could be invoked against following the leadership's position on a referendum on a single currency then, equally, his words could be used to rally support for a beleaguered leadership. Thus, in December 1995, Edward Heath counselled his Conservative backbench colleagues not to defeat the government on a motion on EU fisheries policy. In a neat illustration of the elision between the 'interests of the country' and the 'interests of the government' he advised colleagues 'who represent the fishing industry':

Of course my hon. Friends must take notice of the fishermen in their constituencies, but I also remind them of the remark by Burke so many centuries ago that is often repeated in the House. The purpose and responsibility of a representative is to look after the interests of his constituents, but he must also consider the interests of the country and the community. That is the basis of our work here.

Every hon. Member owes his constituents not only his energy 'but his judgment'. Those were Burke's words. We can offer our fishermen our energy, but my hon. Friends have to make a judgment tonight as to whether it is an event and a matter that justifies their defeating the Government. That is the crucial question to be answered. ${ }^{67}$

In the event the government was defeated by 299 votes to 297 with two Conservative MPs voting against the government and 11 others deliberately abstaining. Edward Heath's plea for Conservative MPs to use 'their judgement' in favour of the government and party loyalty was counterposed by the use of 'independent judgement' to assert the views of a broader conception of the 'interests of the country' beyond partisan considerations. On this occasion Burke and 'trusteeship' prevailed against party and 'delegate' notions of representation. That it did so to no policy effect, other than the Agriculture Minister's pronouncement that due weight would be given to the decision by the House at the next day's European Fisheries Council, did not detract from the fact that MPs were able to legitimate their 'independence' in face of collectivist notions of 'party representation'. 


\section{NOLAN, INTEREST REPRESENTATION AND TRUSTEESHIP}

The continuing strength of trustee notions of representation is also evident in recent concern about 'sleaze' in Westminster. Underpinning the remedial measures taken by the Commons since 1995 there has been a fundamental perception that the legitimacy of parliamentary representation was being eroded by modern practices of interest advocacy. In turn, this perception stemmed from a conception of representation rooted in 'trustee' notions of independence and the belief that MPs represented the nation generally and their constituencies specifically. In the words of Peter Shore: 'The country has a gut feeling that Members of Parliament are here above all to serve them and the nation, and that anything that interferes with that must be justified rather than taken for granted. ${ }^{68}$ This belief shone through the successive resolutions of the House, the Nolan report, and the Code of Conduct adopted by the House in July 1996. The grip of Burkean theory not only within the House but upon academic observers is revealed in Dawn Oliver's statement that 'standards of conduct required of British MPs rest on a number of often unspoken assumptions which reflect the underlying theory of representative democracy ... The established basic theory of representation in the UK is that expressed by Edmund Burke in his Letter to the Electors of Bristol in 1774'. ${ }^{69}$ As Oliver proceeded to note: 'In sum the objections to the various activities [including advocacy of a cause in parliament for payment] were that they affected the exercise by MPs of their judgement in various ways that were contrary to the Burkean theory of representation. ${ }^{10}$

Indeed, the starting point for Nolan's recommendations was the 1947 resolution of the House and, by implication, a reaffirmation of 'trustee' notions of representation. The 1947 resolution prohibited any restrictions on the freedom of MPs to act and speak as they wish, or which caused them to act as representatives of outside bodies. ${ }^{71}$ The Nolan Committee recommended a restatement of this resolution, ${ }^{72}$ and, in November 1995, the House amended the 1947 resolution. Whereas Nolan had proposed only a limited ban on MPs entering into agreements with multi-client consultancies, the amended resolution adopted by the House in November 1995 specifically prohibited paid advocacy for any cause. Despite the reservations of some MPs about the practicalities of drawing a distinction between advice and advocacy, the House agreed to bring greater transparency to the former and to ban the latter. The House also agreed to accept Nolan's recommendations on a Code of Conduct for MPs, the appointment of a Parliamentary Commissioner for Standards, the creation of a new Select Committee on Standards and Privileges (to replace the existing Committees on Privileges and Members' Interests), and for the 
disclosure of income derived from services offered by MPs as

parliamentarians. The Code of Conduct is notable in that it seeks to 'provide a framework within which acceptable conduct should be judged'. ${ }^{73}$ It is also notable for our purposes because at the heart of that framework is the Burkean belief that 'Members have a general duty to act in the interests of the nation as a whole; and a special duty to their constituents' and that to perform this duty members must have 'complete independence in Parliament'. ${ }^{74}$

\section{CONCLUSION}

Burkean notions of the exercise of 'enlightened conscience' on the part of representatives are invariably dismissed as anachronistic in the 1990s. For some Burke is simply 'a voice from a distant past' unsuited to the age of modern party politics, ${ }^{75}$ for others, however, the continued invocation of Burke is more perplexing because, 'despite some 200 years of democratic advance, we appear to be content to let some of the most sensitive and important matters in society be determined in accordance with the political orthodoxy of the 18 th century'. ${ }^{76}$ That this remains so is a reflection of the fact that the 'orthodoxy' of trusteeship has never been fully superseded by other later conceptions of representation. In turn, this reflects the fact that 'trusteeship' encapsulates the basic principles of representation: consent, authorisation, accountability and responsibility. Representatives in parliament are able to inform themselves of the changing balance of opinion in the country and to shape public policy accordingly. In using their 'enlightened conscience' or their 'full freedom to act in their own judgements', MPs do so on the understanding that their constituents expect them to promote both constituency interests and the long-term interests of society as a whole. By this view, only the collective deliberation of all representatives in parliament will produce these objectives. Through the process of deliberation, representatives not only shape but also legitimise public policy. Moreover, any lasting discrepancy between MPs and their constituents would reveal a pathological condition to be rectified through the ballot box.

In this respect, 'trustee' notions provided the frame within which later collectivist ideas of representation developed. Given the potency of trustee theories in the legitimation of public policy, in that legislative outputs were deemed to be legitimate precisely because they had been subject to the process of deliberation by representatives of all sections of the 'political nation' (however defined at the time), collectivist theories could not in themselves displace these notions. Instead, they have coexisted - often uneasily - with the continuing belief that 'Our MPs are representatives of 
the people, not delegates. We expect them to exercise their own judgement, not simply to reflect ours'. ${ }^{77}$ What is noteworthy about this statement is that it was made at the end of the twentieth century, not at the end of the eighteenth century. The ghost of Burke continues to haunt British parliamentary politics!

\section{NOTES}

1. This article is based upon chapter 3 of David Judge, Representation: Theory and Practice in Britain (London: Routledge, 1999).

2. P. Cowley, 'Unbridled Passions? Free Votes, Issues of Conscience, and the Accountability of Members of Parliament', Journal of Legislative Studies, 4 (1998), p.75.

3. P. Cowley and M. Stuart, 'Sodomy, Slaughter, Sunday Shopping and Seatbelts', Party Politics, 3 (1997), pp.19-30.; C.J. Pattie, R.J. Johnston and M. Stuart, 'Voting Without Party?', in P. Cowley (ed.), Conscience and Parliament (London and Portland, OR: Frank Cass, 1998).

4. Cowley, 'Unbridled Passions', p.85.

5. It might be argued that 'trusteeship' in Burke's theory relates essentially to the idea that government in general is a trust to be exercised in the interest of beneficiaries. In this sense Burke's concept of representation is concerned with 'an aristocracy of virtue and wisdom governing for the good of the entire nation'; H. Pitkin, The Concept of Representation (Berkeley, CA: University of California Press, 1967), p.172. However, other interpretations of Burke's work allow explicitly for the view that 'the first Burkean concept of representation, that of rule of the whole nation by a rational elite, is no longer sufficient; there is [a second concept of] representation of particular constituencies by particular members of Parliament' (Pitkin, The Concept of Representation, p. 174). This view is reinforced in Williams' observation that for 'Burke the role of the representative is to exercise practical wisdom to identify the common good. This activity requires a dependence on constituents both to ensure that the House of Commons remains a power independent of the crown and to ensure a degree of sympathy between representatives and the people. Such sympathy will enable representatives to be aware of and inclined to act on their constituents' interests ... but it does not entail any obligation to follow constituents' instructions'; M.S. Williams, 'Burkean "Descriptions" and Political Representation', Canadian Journal of Political Science, 29 (1996), p.31. See also T. Christiano, The Rule of the Many (Boulder, CO: Westview Press, 1996), pp.213-15.

6. S.H. Beer, Modern British Politics (London: Faber \& Faber, 1965), p.13.

7. A.H. Birch, Representative and Responsible Government (London: Unwin, 1964), p.28.

8. Pitkin, The Concept of Representation, p.171.

9. Pitkin, The Concept of Representation, p.171.

10. Pitkin, The Concept of Representation, p.174.

11. E. Burke, 'Speech at Bristol Previous to the Election', in Works, vol.4 (London: Rivington, [1780] 1801), p.70.

12. Burke, 'Speech at Bristol at the Conclusion of the Poll', in Works, vol.4 (London: Rivington, [1780] 1801), p.73.

13. F.P. Canavan, The Political Reason of Edmund Burke (Durham, NC: Duke University Press, 1960), p.158.

14. E. Burke, 'Letter to Sir Hercules Langrishe', in Works, vol.6 (London: Rivington, [1792] 1801), p. 360 .

15. E. Burke, 'Letter to Sir Hercules Langrishe', p.360.

16. Pitkin, The Concept of Representation, p.178.

17. E. Burke, 'Speech on a Bill for Shortening the Duration of Parliament', in Works, vol.10 (London: Rivington, [1780c] 1812), p.79. 
18. E. Burke, 'Speech to the Electors of Bristol', in Works, vol.3 (London: Rivington, ([1774] $1801)$, p. 19.

19. Pitkin, The Concept of Representation, p. 181.

20. Burke, 'Speech on a Bill for Shortening the Duration of Parliament', p.76.

21. O' Gorman, Edmund Burke: His Political Philosophy (London: Allen \& Unwin, 1973), p.40.

22. E. Burke, 'Speech on a Plan for the Better Scrutiny of the Independence of Parliament and the Economic Reformation of the Civil and Other Establishments', in Works, vol.3 (London:Rivington, [1780d] 1801), p.344.

23. Burke, 'Speech on a Plan for the Better Scrutiny of the Independence of Parliament', p.344.

24. O'Gorman, Edmund Burke: His Political Philosophy, p.54.

25. E. Burke, 'Letter 26 February 1790', in A. Cobban and R.A. Smith, The Correspondence of Edmund Burke, vol.6 (Cambridge: Cambridge University Press, [1790] 1967).

26. Burke, 'Speech to the Electors of Bristol', p.20.

27. Burke, 'Speech to the Electors of Bristol', p.20.

28. Burke, 'Speech to the Electors of Bristol', p.20.

29. O'Gorman, Edmund Burke: His Political Philosophy, p.55.

30. F. Bealey, Democracy in the Contemporary State (Oxford: Clarendon Press, 1988), p.40.

31. M. Harrop and W.L. Miller, Elections and Voters: A Comparative Introduction (Basingstoke: Macmillan, 1987), p.247.

32. F. Allaun, I. Mikardo and J. Sillars, Labour: Party or Puppet? (London: Tribune Group, 1972).

33. HC Debates, 1 April 1987, vol.113, col.1174.

34. The Guardian, 25 Feb. 1994.

35. Peter Luff, HC Debates, 15 May 1997, vol.294, col.234.

36. Manifestly voting behaviour in the House of Commons remains primarily focused on 'party', see P. Norton, Dissension in the House of Commons 1945-74 (London: Macmillan, 1975); P. Norton, Dissension in the House of Commons 1974-79 (Oxford: Oxford University Press, 1980); P. Cowley and P. Norton, 'Rebels and Rebellions: Conservative MPs in the 1992 Parliament', paper presented at the PSA Annual Conference, 7-9 April 1998, Keele University. On 'constituency' and 'interest' representation, see P. Norton and D.M. Wood, Back From Westminster: British Members of Parliament and Their Constituents (Lexington,KY: University Press of Kentucky, 1993); P. Norton, 'The United Kingdom: Restoring Confidence', Parliamentary Affairs, 50 (1997), pp.357-72; D. Judge, Representation: Theory and Practice in Britain, pp.97-120, 151-7.

37. D. Judge, Backbench Specialisation in the House of Commons (London: Heinemann Educational Books 1981), p.43.

38. Birch, Representative and Responsible Government, p.227.

39. Cm 2850-II, Standards in Public Life, First Report of the Committee on Standards in Public Life (London: HMSO, 1995), p.71.

40. Cowley and Stuart, 'Sodomy, Slaughter, Sunday Shopping and Seatbelts', p.123.

41. Cowley, 'Unbridled Passions?', p.84.

42. HC Debates, 21 Feb. 1994, vol.238, col.46.

43. HC Debates, 1 April 1987, vol.113, col.1149.

44. Garel-Jones, HC Debates, 21 Feb. 1994, vol.238, col.108.

45. Rhodes Boyson, HC Debates, 21 Feb. 1994, vol.238, col.52.

46. Elizabeth Peacock, HC Debates, 21 Feb. 1994, vol.238, col.33.

47. HC Debates, 21 Feb. 1994, vol.238, col.52.

48. HC Debates, 21 Feb. 1994, vol.238, col.33.

49. HC Debates, 11 June 1997, vol.295, col.1160.

50. Cm 3782, Rights Brought Home: The Human Rights Bill (London: Stationery Office, 1997), para.4.13.

51. Dominic Grieve, HC Debates, 20 May 1998, vol.312, col.989.

52. HC Debates, 20 May 1998, vol.312, col.1006.

53. Norman Godman, HC Debates, 20 May 1998, vol.312, col.1002.

54. HC Debates, 20 May 1998, vol.312, col.1004.

55. HC Debates, 20 May 1998, vol.312, col.1004. 
56. The Study of Parliament Group was founded in 1964 and consists of academics and officers of the two UK Houses of Parliament. The 1992 study was supported by the Nuffield Small Grant Scheme and the 1997 study was funded by an ESRC award (RO 000222470).

57. J.B. Burnell, Democracy and Accountability in the Labour Party (Nottingham: Spokesman, 1980), p.14.

58. The Guardian, 1 Aug. 1980.

59. D. Hayter, 'Democracy at Stake', New Socialist (March/April 1982), pp.13-14.

60. The Times, 15 Sept. 1992.

61. The Independent, 18 Dec. 1990.

62. The Observer, 23 June 1996.

63. The Guardian, 28 June 1996.

64. D. Baker, A. Gamble and S. Ludlam, 'Whips or Scorpions? Conservative MPs and the Maastricht Paving Motion Vote', Parliamentary Affairs, 46 (1993), pp.151-66; D. Baker, A. Gamble and S. Ludlam, 'The Parliamentary Siege of Maastricht 1993', Parliamentary

Affairs, 47 (1994), pp.61-72; S. Ludlam, 'The Spectre Haunting Conservatism: Europe and Backbench Rebellion', in S. Ludlam and M.J. Smith (eds.), Contemporary British

Conservatism (Basingstoke: Macmillan, 1996).

65. Tim Renton, HC Debates, 13 Feb. 1995; vol.254, col.692.

66. HC Debates, 13 Feb. 1995; vol.254, col.703.

67. HC Debates, 19 Dec. 1995, vol.268, col.1362

68. HC Debates, 6 Nov. 1995, vol.265, col.635

69. D. Oliver, 'Regulating the Conduct of MPs: The British Experience of Combating

Corruption', Political Studies, 45 (1997), p.544.

70. Oliver, 'Regulating the Conduct of MPs', p.547.

71. The 1947 resolution stated: 'It is inconsistent with the dignity of the House, with the duty of a Member to his constituents, and with the maintenance of the privilege of freedom of speech, for any Member of this House to enter into a contractual agreement with an outside body, controlling or limiting the Member's complete independence and freedom of action in Parliament or stipulating that he shall act in any way as the representative of such outside body in regard of any matters transacted in Parliament; the duty of a Member being to his constituents and to the country as a whole, rather than to any particular section thereof, cited in HC 108, The Interests of Chairmen and Members of Select Committees, First Report from the Select Committee on Members' Interests, Session 1990-91 (London: HMSO, 1991).

72. Cm 2850, Standards in Public Life, First Report of the Committee on Standards in Public Life (London: HMSO, 1995), p.32.

73. HC 688, The Code of Conduct together with the Guide to the Rules Relating to the Conduct of Members, Session 1996-97 (London: HMSO, 1996), p.1.

74. HC 688, The Code of Conduct, p.1.

75. John Lloyd, The Scotsman, 17 Nov. 1997.

76. P. Cowley, 'Unbridled Passions?', paper presented at conference on 'Reform in British

Politics', Wroxton College, 9-10 Aug. 1997, p.16.

77. Tim Luckhurst, The Scotsman, 17 Oct. 1997. 